\title{
Constitutive Activation of Gas within Forebrain Neurons Causes Deficits in Sensorimotor Gating Because of PKA-Dependent Decreases in CAMP
}

\author{
Michele P Kelly*, 1,2 , Carolina Isiegas', York-Fong Cheung ${ }^{3}$, Jan Tokarczyk ${ }^{2}$, Xioaju Yang ${ }^{4}$, \\ Michael F Esposito', David A Rapoport', Sara A Fabian', Steven J Siegel', Gary Wand ${ }^{4}$, \\ Miles D Houslay ${ }^{3}$, Stephen J Kanes ${ }^{2}$ and Ted Abel' \\ 'Department of Biology, University of Pennsylvania, Philadelphia, PA, USA; ${ }^{2}$ Department of Psychiatry, University of Pennsylvania, Philadelphia, \\ PA, USA; ${ }^{3}$ Division of Biochemistry and Molecular Biology, University of Glasgow, Glasgow, UK; ${ }^{4}$ Department of Endocrinology and Metabolism, \\ Johns Hopkins University, Baltimore, MD, USA
}

\begin{abstract}
Sensorimotor gating, the ability to automatically filter sensory information, is deficient in a number of psychiatric disorders, yet little is known of the biochemical mechanisms underlying this critical neural process. Previously, we reported that mice expressing a constitutively active isoform of the G-protein subunit Gas (Gas*) within forebrain neurons exhibit decreased gating, as measured by prepulse inhibition of acoustic startle (PPI). Here, to elucidate the biochemistry regulating sensorimotor gating and to identify novel therapeutic targets, we test the hypothesis that Gas* causes PPI deficits via brain region-specific changes in cyclic AMP (cAMP) signaling. As predicted from its ability to stimulate adenylyl cyclase, we find here that Gas* increases cAMP levels in the striatum. Suprisingly, however, Gas* mice exhibit reduced cAMP levels in the cortex and hippocampus because of increased cAMP phosphodiesterase (CPDE) activity. It is this decrease in CAMP that appears to mediate the effect of Gas* on PPI because Rp-cAMPS decreases PPI in C57BL 6) mice. Furthermore, the antipsychotic haloperidol increases both PPI and cAMP levels specifically in Gas* mice and the cPDE inhibitor rolipram also rescues PPI deficits of Gas* mice. Finally, to block potentially the pathway that leads to cPDE upregulation in Gas* mice, we coexpressed the $R(A B)$ transgene (a dominant-negative regulatory subunit of protein kinase $A(P K A)$ ), which fully rescues the reductions

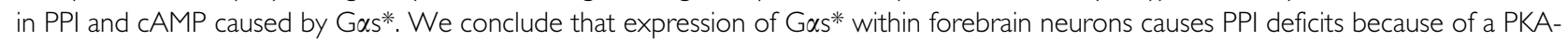
dependent decrease in CAMP and suggest that CAMP PDE inhibitors may exhibit antipsychotic-like therapeutic effects.

Neuropsychopharmacology (2007) 32, 577-588. doi: I0.1038/sj.npp. I 301099; published online 3I May 2006
\end{abstract}

Keywords: GNAS; Gs alpha; preattentional processing; schizophrenia; Tourette's syndrome; genetic mouse model

\section{INTRODUCTION}

Sensorimotor gating is a fundamental neural process whereby a sensory event leads to the inhibition of a subsequently elicited motor response (Graham, 1975). One popular model used in the study of sensorimotor gating is prepulse inhibition of acoustic startle (PPI). PPI is a behavioral paradigm in which the presentation of a nonstartling stimulus (prepulse, eg $72 \mathrm{~dB}$ noise) inhibits the startle response elicited by a subsequently presented startling acoustic stimulus (eg $120 \mathrm{~dB}$ noise). The extent to

*Correspondence: Dr MP Kelly, Department of Biology, University of Pennsylvania, 319 Leidy Labs, 3740 Hamilton Walk, Philadelphia, PA 19104, USA, Tel: + | 2158983155 , Fax: + I 2158988780 ,

E-mail: mpkelly@bbl.med.upenn.edu

Received 24 October 2005; revised 5 April 2006; accepted 5 April 2006

Online publication: 17 April 2006 at http://www.acnp.org/citations/ Npp04 1706050643/default.pdf which an animal inhibits the subsequent startle response is thought to reflect the animal's ability to automatically filter out extraneous sensory information (Braff et al, 2001). Reduced PPI has been observed in several psychiatric and neurological illnesses, including - but not limited to - autism (Perry et al, 2006), Fragile X syndrome (Frankland et al, 2004), panic disorder (Ludewig et al, 2005), manic depression (Perry et al, 2001), obsessive compulsive disorder (Hoenig et al, 2005), Huntingtons' disease (Swerdlow et al, 1995), schizophrenia (Braff et al, 1978), and Tourette's syndrome (Castellanos et al, 1996). PPI deficits are particularly relevant to the study of schizophrenia and Tourette's syndrome because the ability of a drug to increase PPI in rodents predicts the clinical efficacy of medications specifically used to treat these patient populations (Swerdlow and Geyer, 1998; Geyer et al, 2001; Sandor, 2003). Although much has been learned of the neural circuitry and the neurotransmitters regulating PPI, relatively little is known about the biochemical mechanisms underlying this neural process. Given the predictive validity 
of the PPI model, understanding the intracellular molecules regulating this behavior may lead to the development of novel therapeutics. In fact, drugs that target widespread intracellular signaling cascades may prove ideal given that polypharmacological antipsychotics (ie drugs that bind to multiple receptors) are more clinically efficacious than drugs that bind to a single receptor (Frantz, 2005). Thus, we seek to define intracellular signaling events that regulate PPI in order to advance our mechanistic understanding of psychiatric illness and to identify new and improved therapeutic interventions.

Indirect evidence has suggested the cyclic AMP (cAMP) second messenger cascade (Figure 1a) may be one of the intracellular signaling pathways that regulates PPI. Amphetamine, an indirect dopaminergic agonist, decreases PPI via dopamine D2 receptors (Ralph-Williams et al, 2002) that inhibit AC activity (Neves et al, 2002). Conversely, haloperidol, a typical antipsychotic that blocks D2 receptors (cf., Miyamoto et al, 2005) and increases cAMP signaling in forebrain structures (Berndt and Schwabe, 1973; Kaneko et al, 1992; Kaplan et al, 1999; Dwivedi et al, 2002; but see Kebabian et al, 1972; Carenzi et al, 1975), increases PPI (Ouagazzal et al, 2001). Thus, there appears to be a relationship between cAMP and PPI levels. Further, decreased levels of cAMP could result from either a hypoglutamatergic state (via reduced calcium/calmodulin stimulation of AC; Chetkovich and Sweatt, 1993) or a hyperdopaminergic state (via D2, 3, 4 receptor-mediated inhibition of AC; Neves et al, 2002), both of which are commonly hypothesized to contribute to endophenotypes of schizophrenia, such as PPI deficits (Sawa and Snyder, 2002). Interestingly, decreased cAMP levels have been observed in the cortex and striatum of patients with Tourette's syndrome (Singer et al, 1990) and reduced production of cAMP has been noted in platelets of patients with schizophrenia (Kaiya, 1992).

One component of the cAMP cascade is the G-protein subunit $G \alpha s \quad\left(G \alpha s^{*}\right)$ (Figure 1). G $\alpha$ s couples several neurotransmitter receptors, including the dopamine D1/ D5 receptors, to AC (Neves et al, 2002). Acutely, G $\alpha$ s stimulates AC resulting in increased levels of cAMP (Figure 1a; Neves et al, 2002); however, compensatory degradation of cAMP by phosphodiesterases (PDEs) counteracts chronic $\mathrm{G} \alpha$ s signaling in select cell types (Figure 1a; eg Lania et al, 1998). Gas signaling is of particular interest in the study of endophenotypes of schizophrenia, because increased activity of this protein has been noted in the striatum and leukocytes of patients with schizophrenia (Memo et al, 1983; Avissar et al, 2001). Further, a polymorphism, which results in increased mRNA expression of $\mathrm{G} \alpha$ s (Frey et al, 2005), has recently been genetically linked to schizophrenia (Minoretti et al, 2006). Interestingly, transgenic mice expressing a constitutively active isoform of $\mathrm{G} \alpha \mathrm{s}\left(\mathrm{G} \alpha \mathrm{s}^{*}\right)$ show decreased PPI (Gould et al, 2004).

Based on the evidence above indicating decreased cAMP signaling in PPI deficits, we hypothesized that PPI deficits in $\mathrm{G} \alpha \mathrm{s}^{*}$ mice are because of decreased cAMP levels caused by a compensatory mechanism(s) downstream of AC, such as increased cAMP PDE activity. Interestingly, a possible role of increased cAMP PDE activity in the etiology of schizophrenia has been recently suggested. Millar et al

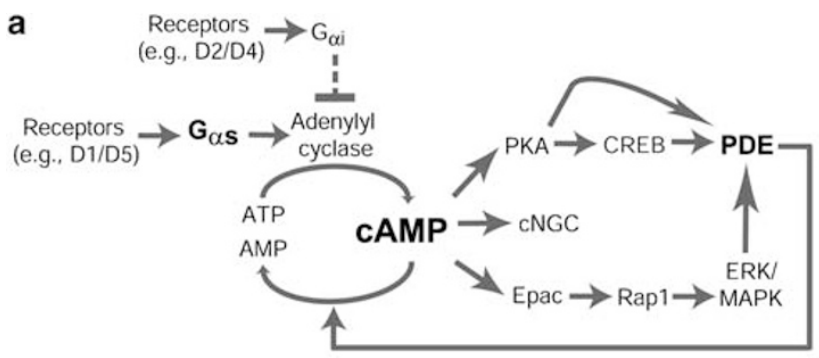

b

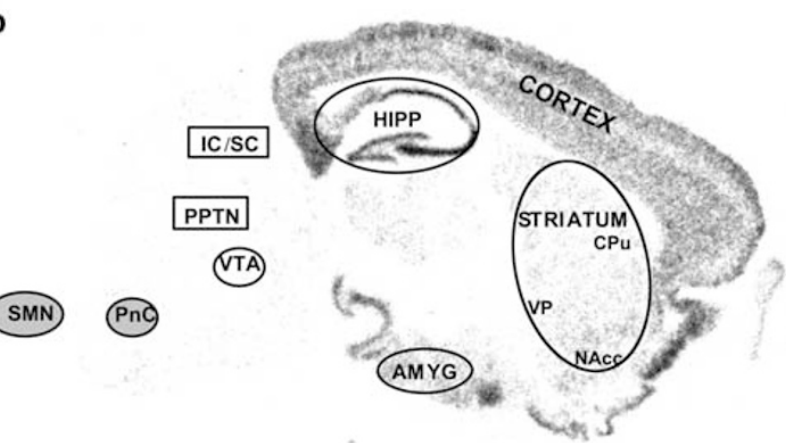

Figure I Schematic of G-protein signal-transduction cascade and autoradiograph of G $\alpha s^{*}$ transgene expression. (a) Following extracellular stimulation of neurotransmitter receptors, intracellular G-protein subunits transduce signals to effector molecules, such as adenylyl cyclase. Gas activates adenylyl cyclase (indicated by solid line), stimulating cAMP formation, and Gai inhibits adenylyl cyclase (indicated by broken line). CAMP activates multiple downstream targets including CAMP-dependent PKA, cyclic-nucleotide-gated channels (cNGC), and Epac (Kopperud et al, 2003). Negative feedback on CAMP signaling occurs via net increased activity of CPDE, which degrade CAMP (Beavo and Brunton, 2002; Lee et al, 2002; Murthy et al, 2002; Houslay and Adams, 2003; Rochais et al, 2004). Crosstalk between members of the CREB and MAPK pathways have not been illustrated for sake of graphic clarity. (b) Autoradiographic in situ hybridization (sagital section) shows that expression of the constitutively active G $\alpha s^{*}$ transgene is restricted to forebrain regions, as described previously (Wand et al, 200I). The brain regions underlying the acoustic startle response (shaded ovals), mediation of prepulse inhibition (unshaded rectangles), and modulation/regulation of prepulse inhibition (unshaded ovals and cortex; Koch, 1999; Swerdlow et al, 200la) are labeled to emphasize which brain regions are of interest in the current experiments: the cortex, hippocampus, striatum, and amygdala. The contribution of specific subregions of cortex (eg temporal vs frontal) and hippocampus (dorsal vs ventral) have not been indicated separately. AMYG-amygdala; CPu - caudate putamen; HIPP_hippocampus; IC/SC — inferior/superior colliculus; NAcc - nucleus accumbens; PnC - pontine reticular nucleus; PPTN_pedunculopontine tegmental nucleus; SMN_-spinal motoneurons; VP_ventral pallidum; and VTA — ventral tegmental area.

(2005) show that the disrupted in schizophrenia 1 (DISC 1) protein normally sequesters PDE4 (inhibiting activity); thus, a loss of DISC1 could result in increased PDE4 activity. To determine if decreased cAMP signaling is responsible for the effect of $\mathrm{G} \alpha \mathrm{s}^{*}$ on PPI, we measured cAMP levels and cAMP PDE activity across several brain regions in these transgenic mice. Further, using either $\mathrm{G} \alpha \mathrm{s}^{*}$ transgenic mice or $\mathrm{C} 57 \mathrm{BL} / 6 \mathrm{~J}$ mice, we determined the biochemical and/or behavioral effects of several manipulations that alter cAMP signaling including amphetamine, haloperidol, the competitive inhibitor of cAMP binding Rp-cAMPS, and the PDE4 inhibitor rolipram. In addition, because compensatory increases in cAMP PDE activity are protein kinase A (PKA)-dependent (Lee et al, 2002; Murthy 
et al, 2002; Houslay and Adams, 2003; Rochais et al, 2004), we tested the effects of crossing $\mathrm{G} \alpha \mathrm{s}^{*}$ transgenic mice to another line of transgenic mice expressing the PKA inhibitor $\mathrm{R}(\mathrm{AB})$ (Abel et al, 1997). Together, our results show that $G \alpha s^{\star}$ expression results in a complex, brainregion-specific biochemical response that ultimately leads to deficits in PPI.

\section{MATERIALS AND METHODS}

\section{Subjects}

$\mathrm{G} \alpha \mathrm{s}^{*}$ and $\mathrm{R}(\mathrm{AB})$ transgenic mice were bred and grouphoused in breeding colonies at the University of Pennsylvania in a hemizygous state on a C57BL/6J background (N10-N13). For each experiment, 2 to 6 month-old, sexmatched, wild-type (WT) littermates were run in parallel to transgenic mice. For experiments examining coexpression of $\mathrm{G} \alpha \mathrm{s}^{*}$ and $\mathrm{R}(\mathrm{AB})$, a hemizygous $\mathrm{G} \alpha \mathrm{s}^{*}$ transgenic mouse was mated to a hemizygous $\mathrm{R}(\mathrm{AB})$ transgenic mouse (each backcrossed to C57BL/6J N10-N13), and all offspring were compared (WT, G $\alpha s^{*}$ transgenic, $\mathrm{R}(\mathrm{AB})$ transgenic, $\mathrm{G} \alpha \mathrm{s}^{*}$, and $\mathrm{R}(\mathrm{AB})$ bitransgenic). As described previously (Wand et al, 2001; Gould et al, 2004), G $\alpha \mathrm{s}^{*}$ transgenic mice express an isoform of the $G \alpha s^{*}$ that is constitutively active because of a point mutation (Q227L) that prevents hydrolysis of bound GTP, resulting in significantly increased basal adenylyl cyclase activity (Wand et al, 2001). This transgene is expressed in addition to the endogenous genomic copy of $\mathrm{G} \alpha \mathrm{s}$, which we have verified remains functional (as indicated by increased adenylyl cyclase activity in response to GTP $\gamma$ S stimulation; data not shown). As described previously (Abel et al, 1997), $\mathrm{R}(\mathrm{AB})$ mice express a dominant-negative regulatory subunit for PKA, resulting in inhibited PKA activity. Expression of both the Gas* and $\mathrm{R}(\mathrm{AB})$ transgenes are driven by the CaMKII $\alpha$ promoter, which restricts expression to postnatal forebrain neurons (see Figure $1 \mathrm{~b}$ for expression pattern). Animals were genotyped by Southern blot using a transgene-specific probe as described (Abel et al, 1997); however, all experiments were conducted by personnel blind to genotype. For experiments employing C57BL/6J mice, 2 to 5month-old male and female subjects were either bred inhouse or were obtained from Jackson Laboratories and group housed in our breeding facilities for a minimum of 1 week before testing. All experiments were carried out based on National Institutes of Health guidelines for the care and use of laboratory animals and were fully approved by the Institutional Animal Care and Use Committee of the University of Pennsylvania.

\section{Use of Subjects}

In the haloperidol study (see Drug preparation below), animals were tested under both vehicle and drug conditions in a counterbalanced manner (half received vehicle first and half received drug first), with testing under each of the two treatments separated by a minimum of 1 week. Control and transgenic mice ( $n=16 / 16$, respectively) were first tested in the experiment examining effects of $1.0 \mathrm{mg} / \mathrm{kg}$ haloperidol. A portion of these animals $(n=8 / 7)$ were retested, in a counterbalanced manner, in the experiment examining the effects of $0.1 \mathrm{mg} / \mathrm{kg}$ haloperidol on PPI. Additional naive animals $(n=3 / 4)$ were also tested under vehicle and $0.1 \mathrm{mg} /$ $\mathrm{kg}$ haloperidol. This latter group of animals was subsequently used in analyses of cortical, hippocampal, and cerebellar cAMP levels in response to vehicle or $0.1 \mathrm{mg} / \mathrm{kg}$ haloperidol. Additional control and transgenic animals (that had not undergone any PPI testing; $n=8 / 9$ ) were also used in these analyses. The decision to measure striatal cAMP in response to vehicle or $0.1 \mathrm{mg} / \mathrm{kg}$ haloperidol came at a later time, thus requiring a separate set of naive control and transgenic mice $(n=9 / 9)$. In pharmacological experiments employing C57BL/6J mice, separate groups of animals were tested under vehicle or drug, and behaviorally tested animals were not reused for biochemical analyses. In the $G \alpha s \times R(A B)$ studies, separate groups of animals were used for behavioral and biochemical testing. Finally, in the rolipram study, naive animals were tested under both vehicle and drug conditions in a counterbalanced manner (half received vehicle first and half received drug first), with testing under each of the two treatments separated by a minimum of 1 week. Please see figure legends for the total number of animals $(n=)$ in each experimental group.

\section{Biochemistry}

For biochemical experiments, animals were killed by cervical dislocation and brains were immediately harvested, dissected, and placed on dry ice. Temporal cortex, hippocampus, striatum, amygdala, and cerebellum were collected from either the left or right hemisphere. $A C$ activity (basal) of membrane preparations was measured from the hippocampus and cortex in triplicate by a modification of the method by Salomon et al (1974). Aliquots $(10 \mu \mathrm{g})$ of membrane protein were assayed in $100 \mu \mathrm{l}$ final volume containing $0.1 \mathrm{mM}\left[\alpha^{-32} \mathrm{P}\right]$ ATP $(1 \mathrm{pCi})$, $2.8 \mathrm{U}$ of creatine phosphokinase, $5 \mathrm{mM}$ creatine phosphate, $1.5 \mathrm{mM} \mathrm{MgCl} \mathrm{19.2 \%} \mathrm{BSA,} 50 \mathrm{mM} \mathrm{Na-Hepes} \mathrm{(pH} \mathrm{7.6),}$ $0.3 \mathrm{mM} \mathrm{KCI}, 0.2 \mathrm{mM}$ cAMP, and $1 \mathrm{mM}$ dithiothreitol. Samples were incubated at $30^{\circ} \mathrm{C}$ for $30 \mathrm{~min}$ with no further additions. The reaction was terminated by adding $100 \mu \mathrm{l}$ of $50 \mathrm{mM}$ Hepes (pH 7.5), $2 \mathrm{mM}$ ATP, $0.5 \mathrm{mM}$ cAMP, $2 \%$ SDS, tritiated cAMP $(15 \mathrm{nCi})$ to each tube, and heating to $100^{\circ} \mathrm{C}$ for 3 min. cAMP was isolated by chromatography. Total cAMP PDE activity (basal) was measured in the cortex, hippocampus, striatum, and cerebellum, as described previously (MacKenzie et al, 2002), using a standard concentration of cAMP $(1 \mu \mathrm{m})$. Levels of $c A M P$ were measured from a single hemisphere using a radioimmune competition assay kit (Perkin-Elmer, Wellesley, MA). To measure basal AC activity, cAMP levels, and cAMP PDE activity, animals were killed from the home cage. To measure the effects of haloperidol on cAMP levels, WT and $\mathrm{G} \alpha \mathrm{s}^{\star}$ transgenic mice received an intraperitoneal (i.p.) injection of either vehicle or $0.1 \mathrm{mg} / \mathrm{kg}$ haloperidol, were singly housed for $30 \mathrm{~min}$, and were then killed. For the amphetamine study, C57BL/6J mice received an i.p. injection of vehicle or $10 \mathrm{mg} / \mathrm{kg}$ dextro-amphetamine (Damphetamine) and were singly housed for $15 \mathrm{~min}$ before killing in order to parallel the delay between injection and onset of PPI trials. 


\section{Drug Preparation}

For i.p. experiments, D-amphetamine Sigma-Aldrich, St Louis, MO) was dissolved in saline $(1 \mathrm{mg} / \mathrm{ml})$ and administered at a dose of $10 \mathrm{mg} / \mathrm{kg}$. Haloperidol (Ben Venue Laboratories Inc., Bedford, $\mathrm{OH}$ ) was dissolved in saline with lactic acid, ( $\mathrm{pH} 3.0-3.8)(0.01$ or $0.1 \mathrm{mg} / \mathrm{ml})$ and administered at a dose of $0.1 \mathrm{mg} / \mathrm{kg}$ or $1.0 \mathrm{mg} / \mathrm{kg}$. Rolipram (SigmaAldrich, St Louis, MO) was dissolved in 2\% DMSO in saline $(0.066 \mathrm{mg} / \mathrm{ml})$ and administered at a dose of $0.66 \mathrm{mg} / \mathrm{kg}$. Doses for all i.p. experiments were chosen based on pilot dose-response curves in C57BL/6J mice (data not shown).

For intracerebroventricular (i.c.v.) experiments, RpcAMPS, a competitive inhibitor of cAMP binding (Biolog, Germany), was dissolved in distilled water. Initial experiments utilized doses of Rp-cAMPS previously shown to impair learning and memory (Bourtchouladze et al, 1998); however, these high doses (55-110 nmol) drastically suppressed startle responses, making interpretation of PPI difficult (data not shown). Therefore, experiments reported here utilize a much lower dose of $5.5 \mathrm{nmol}$ in $3 \mu \mathrm{l}$ water.

\section{Surgeries}

At 8-10 weeks of age, group-housed C57BL/6J mice were anesthetized with isoflurane, placed in a stereotaxic frame (David Kopf, Tujunga, CA ), and then implanted with a 22-Gauge guide cannula (Plastics One Inc., Roanoke, VA) into the lateral ventricle (anteroposterior from the bregma $-0.4 \mathrm{~mm}$, lateral $1.1 \mathrm{~mm}$, and $2.3 \mathrm{~mm}$ in depth). A dummy cannula was then inserted into the guide cannula to prevent clogging. Following the surgery, mice were singly housed to ensure recovery. On days 5 and 6 (postsurgery), mice were gently handled. On day 7 or 8 (postsurgery), mice were injected i.c.v. by placing a needle through the guide cannula, which was connected to a microsyringe (Hamilton, Reno, NV) via a polyethylene tube. Drug was delivered over a 1-min window, using a microinfusion pump (Harvard, Holliston, MA), and the needle remained in place an additional $30 \mathrm{~s}$ to allow for diffusion of the drug. To verify cannulae placement, animals were killed after testing and their brains coronally sectioned $(20 \mu \mathrm{m}$ sections) with a cryostat. Cannula tracks were plainly visible upon Nissl staining, and placement within the ventricle was confirmed by an investigator blind to treatment condition. Two animals (one from each group) were determined to have a misplaced cannula and, thus, were dropped from analyses.

\section{PPI}

Startle responses to acoustic stimuli and inhibition of startle responses because of presentation of a nonstartling acoustic prepulse were measured as described previously (protocol 2; Gould et al, 2004), except that background was set to $68 \mathrm{~dB}$. Briefly, startle responses were measured by an accelerometer in response to acoustic stimuli delivered by a white noise generator (4-19 kHz; SR-Lab, San Diego, CA). Sessions began with a 5 min block of acclimation to the $68 \mathrm{~dB}$ background noise, followed by a $10 \mathrm{~min}$ block of startle trials varying from 95 to $120 \mathrm{~dB}$ (data not presented here). Startle trials were followed by a 10 min block of PPI trials. Each prepulse trial consisted of a $20 \mathrm{~ms} 72,76$, or

$84 \mathrm{~dB}$ nonstartling prepulse followed $100 \mathrm{~ms}$ later by a $40 \mathrm{~ms}$ startling pulse of $120 \mathrm{~dB}$. Five trials of each prepulse intensity, along with 10 startle-only trials (ie trials with no prepulse), were presented in random order. PPI for a given prepulse intensity was calculated as percent inhibition of the startle response using the following formula: (100(average startle response for PPI trials/average startle response for startle-only trials in PPI block)*100).

For pharmacological experiments utilizing i.p. injections, animals were individually housed in holding cages for $30 \mathrm{~min}$, before receiving an i.p. injection of vehicle or drug. Based on previous reports (Ouagazzal et al, 2001; RalphWilliams et al, 2002), animals in the amphetamine experiment were placed immediately into the startle chambers, animals in the haloperidol experiments remained in the holding cages for an additional $30 \mathrm{~min}$, and animals in the rolipram experiments remained in the holding cages for an additional $15 \mathrm{~min}$, to allow for differences in drug kinetics. After the testing session ended, animals were promptly returned to their home cage. For pharmacological experiments using i.c.v. injections, animals were individually housed during the recovery period between surgery and testing (1 week) to reduce the chance of injury or loosening of the cannula. Because these mice were group-housed past the age of puberty, it is unlikely that such a short duration of isolated housing negatively impacted PPI (Bakshi and Geyer, 1999); however, an interaction between the effects of 1 week of individual housing and Rp-cAMPS cannot be strictly ruled out. Following i.c.v. injection of either vehicle or Rp-cAMPS, animals were placed immediately into the startle chamber. Animals were promptly killed following the session to verify cannula placement.

\section{Data Analysis}

Statistical analyses were conducted using Sigmastat (v2.03; Systat, Point Richmond, CA) and Statistica (v6.1; Statsoft, Tulsa, OK). Data were analyzed by $t$-test, analysis of variance (ANOVA), or repeated measures ANOVA (RM ANOVA) as appropriate. In statistical analyses of hippocampal PDE activity and cAMP levels (all regions) following amphetamine, cohorts were paired to increase the power of the $t$-tests performed. When significant effects (between more than two groups) or interactions were found for ANOVAs, post hoc comparisons were made using StudentNewman-Keuls range statistics. Statistical outliers greater than 2SD's from the mean were dropped from analyses. For PPI, effects of genotype, trial, and drug treatment were analyzed. In addition, Pearson's product moment correlations were conducted to determine if there was an interrelation between startle magnitude and \%PPI, as described previously (Quednow et al, 2006). In biochemical experiments, balanced groups of animals were raised at different times and killed on different days. Therefore, to control for variability because of day of killing, data for each group were normalized and expressed as a percentage of the WT (or WT vehicle) mean (but see Table 1 for raw data). Normalized data were then combined and analyzed for effects of genotype and drug treatment. Significance was determined at $p<0.05$. All data are expressed as mean \pm standard error of the mean (SEM). 
Table I Summary of Raw Data (pmol cAMP/mg Protein) for Adenylyl Cyclase (AC), Phosphodiesterase (PDE), and cAMP Assays

\begin{tabular}{|c|c|c|c|c|}
\hline Measure & WT (home cage or veh) & G $\alpha \mathbf{s}^{*}$ (home cage or veh) & & \\
\hline$A C$ & $693.2 \pm 21.6$ & $1494.4 \pm 65.7$ & & \\
\hline Cortex & $386.0 \pm 10.0$ & $802.0 \pm 27.3$ & & \\
\hline \multicolumn{5}{|l|}{ Hippocampus } \\
\hline \multicolumn{5}{|l|}{$P D E$} \\
\hline Hippocampus & $521.8 \pm 31.1$ & $594.0 \pm 26.5$ & & \\
\hline \multicolumn{5}{|l|}{ cAMP-basal } \\
\hline Cortex & $247.1 \pm 16.2$ & $211.7 \pm 13.4$ & & \\
\hline Hippocampus & $383.2 \pm 9.8$ & $350.2 \pm 11.6$ & & \\
\hline \multicolumn{5}{|l|}{ cAMP-haloperidol } \\
\hline Cortex & $164.0 \pm 79.0$ & $101.3 \pm 53.6$ & $137.5 \pm 68.7$ & $155.8 \pm 61.9$ \\
\hline Hippocampus & $223.2 \pm 94.1$ & $142.7 \pm 65.8$ & $217.8 \pm 77.5$ & $232.2 \pm 82.0$ \\
\hline Striatum & $418.1 \pm 23.0$ & $601.1 \pm 83.9$ & $526.9 \pm 61.4$ & $619.6 \pm 46.1$ \\
\hline \multirow[t]{2}{*}{ Cerebellum } & $|44.0 \pm 75|$. & $110.7 \pm 56.5$ & $111.0 \pm 46.5$ & $153.2 \pm 55.8$ \\
\hline & & & $R(A B)$ & $\mathbf{G} \alpha \mathrm{s}^{*} \times \mathbf{R}(\mathrm{AB})$ \\
\hline \multicolumn{5}{|l|}{ cAMP-basal } \\
\hline Cortex & $595.5 \pm 24.7$ & $443.2 \pm 24.5$ & $565.2 \pm 28.0$ & $555.7 \pm 35.9$ \\
\hline Striatum & $124.4 \pm 3.3$ & $189.7 \pm 8.1$ & $127.4 \pm 5.5$ & $173.1 \pm 8.3$ \\
\hline
\end{tabular}

Each row represents a separate experiment. See Results text for statistical analyses of normalized values.

Data expressed as mean \pm SEM. WT—wild-type, veh—vehicle, hal—haloperidol $0.1 \mathrm{mg} / \mathrm{kg}$.

\section{RESULTS}

G $\alpha \mathrm{s}^{\star}$ Expression Reduces cAMP Levels in the Cortex and Hippocampus

Biochemical assays reveal that $\mathrm{G} \alpha \mathrm{s}^{*}$ transgenic mice exhibit region-specific alterations in cAMP levels, AC activity, and cAMP PDE activity. Expression of $G \alpha s^{*}$ is restricted to postnatal forebrain neurons by the use of the CaMKII $\alpha$ promoter; therefore, the brain regions of interest were limited to the striatum, cortex, hippocampus, and amygdala (Figure 1b). Consistent with the previously noted increase in basal AC activity (Wand et al, 2001), Gas* transgenic mice exhibit significantly increased cAMP levels within the striatum relative to WT littermates $\left(\mathrm{t}_{(14)}=4.06, p=0.001\right.$; Figure 2a). Despite the increase in cAMP levels, G $\alpha \mathrm{s}^{*}$ transgenic mice show normal total cAMP PDE activity in the striatum. In sharp contrast, $\mathrm{G} \alpha \mathrm{s}^{\star}$ transgenic mice demonstrate significantly lower levels of cAMP in both the cortex $\left(\mathrm{t}_{(28)}=4.67, p<0.0001\right)$ and the hippocampus $\left(\mathrm{t}_{(29)}=2.39, p<0.05\right)$ relative to WT mice (Figure 2a). These decreases in cAMP are not because of decreased synthesis because $G \alpha s^{*}$ transgenic mice exhibit increased basal AC activity in the cortex (WT, $n=7,100.0 \pm 3.1 \%$; G $\alpha \mathrm{s}^{*}, n=7$, $\left.215.59 \pm 9.5 \% ; \mathrm{t}_{(12)}=11.58, p<0.0001\right)$ and the hippocam- pus (WT, $100.0 \pm 2.6 \% ; \mathrm{G} \alpha \mathrm{s}^{*}, 207.76 \pm 7.1 \% ; \mathrm{t}_{(14)}=14.29$, $p<0.0001)$. Instead, the decreases in cAMP levels within transgenic mice appear to be because of a compensatory increase in total cAMP PDE activity measured in the cortex (WT, $n=14,100.0 \pm 5.3 \% ; \quad G \alpha s^{*}, n=13,119.00 \pm 4.4 \%$; $\left.\mathrm{t}_{(25)}=2.72, \quad p<0.02\right)$ and hippocampus (WT, $n=8$, $\left.100 \pm 5.9 \% ; G \alpha s^{*}, n=8,113.0 \pm 5.3 \% ; \mathrm{t}_{(7)}=2.56, p<0.05\right)$. There is no difference between $G \alpha s^{*}$ transgenic and WT mice in cAMP levels of the amygdala nor in cAMP levels or cAMP PDE activity of the cerebellum, a control region of interest that lacks transgene expression (Figure 2a). Additional experiments were conducted to determine if the increases in striatal cAMP and/or decreases in cortical or hippocampal cAMP mediate the effects of $\mathrm{G} \alpha \mathrm{s}^{\star}$ on PPI.

\section{Amphetamine Decreases PPI and Reduces cAMP Levels Only in the Cortex}

To determine if a pharmacological disruptor of PPI would elicit a regionally specific cAMP response as does $G \alpha s^{*}$ expression, we examined the effects of the indirect dopaminergic agonist amphetamine in C57BL/6J mice. First, we verified that i.p. injection of $\mathrm{D}$-amphetamine $(10 \mathrm{mg} / \mathrm{kg}) v s$ vehicle ( $n=18$ per group) reduces PPI across 

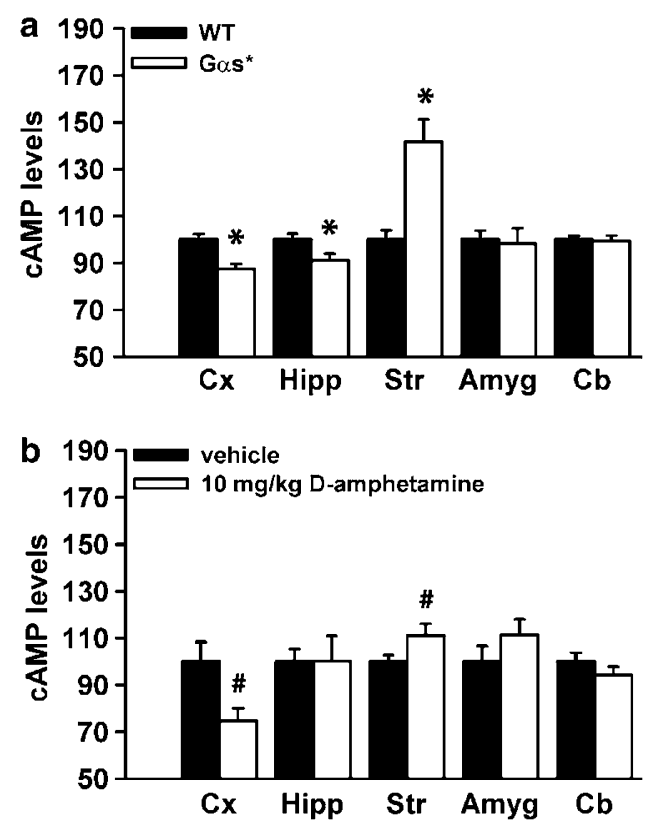

Figure 2 Gas* expression and amphetamine administration decrease CAMP levels in the cortex and increase CAMP levels in the striatum. (a) Relative to WT littermates (WT, $n=8-16)$, Gas* transgenic mice $(n=8-$ 15) with reduced PPI (Gould et al, 2004) show decreased cAMP levels (\% WT) in the cortex (CX) and the hippocampus (Hipp), increased cAMP levels in the striatum (Str), and no change in the amygdala (Amyg) or the cerebellum (Cb). (b) Injection of $10 \mathrm{mg} / \mathrm{kg}$ D-amphetamine i.p. (vs vehicle, $n=15-17$ per group), which reduces PPI, significantly lowers CAMP levels (\% vehicle) in the cortex and increases CAMP levels in the striatum of C57BL/6J mice. Data represented as mean \pm SEM. *vs WT, $p<0.05-0005$; \# $v$ s vehicle, $p<0.05-0.01$.

prepulse intensities in $\mathrm{C} 57 \mathrm{BL} / 6 \mathrm{~J}$ mice (effect of drug: $\left.\mathrm{F}_{(1,68)}=6.37, p<0.05\right)$. Next, we measured the effects of $\mathrm{D}$ amphetamine on cAMP levels in the cortex, hippocampus, striatum, amygdala, and the cerebellum, the same brain regions examined in the $\mathrm{G} \alpha \mathrm{s}^{*}$ mice. Similar to the pattern observed in the $\mathrm{G} \alpha \mathrm{s}^{*}$ mice, D-amphetamine $(10 \mathrm{mg} / \mathrm{kg})$ significantly increases cAMP levels in the striatum $\left(\mathrm{t}_{(16)}=2.28, p<0.05\right.$; Figure $\left.2 \mathrm{~b}\right)$ and reduces cAMP levels in the cortex of C57BL/6J mice $\left(\mathrm{t}_{(14)}=3.19, p<0.01\right)$. There is no effect of $\mathrm{D}$-amphetamine on cAMP levels in the hippocampus, amygdala, nor the cerebellum (Figure $2 b$ ).

\section{Blockade of cAMP signaling within the brain reduces PPI}

To determine if decreasing cAMP signaling within the central nervous system would be sufficient to induce PPI deficits, we tested the effects of i.c.v. injections of RpcAMPS $(5.5 \mathrm{nmol})$, a competitive inhibitor of cAMP binding. Rp-cAMPS significantly decreases PPI in C57BL/ $6 \mathrm{~J}$ mice across trials (effect of drug: $\mathrm{F}_{(1,40)}=9.80, p<0.01$; Figure 3). Analysis of the raw data shows that Rp-cAMPS does not significantly affect startle responses to the $120 \mathrm{~dB}$ startling pulse itself (vehicle 67.63 $\pm 10.2 ;$ Rp-cAMPS $84.26 \pm 11.7 ; \mathrm{t}_{(20)}=1.06$, NS); however, higher doses of $55-110 \mathrm{nmol}$ drastically reduce startle responses (data not shown). The ability of Rp-cAMPS to decrease PPI suggests that reducing cAMP signaling within the central nervous

\section{Haloperidol Selectively Restores PPI and Cortical cAMP Levels of $\mathrm{G} \alpha \mathrm{s}^{\star}$ Transgenic Mice}

Given that blockade of cAMP signaling results in PPI deficits, we determined if 'upstream' augmentation of the cAMP pathway would rescue the PPI deficits observed in $\mathrm{G} \alpha \mathrm{s}^{*}$ transgenic mice. Administration of $1.0 \mathrm{mg} / \mathrm{kg}$ haloperidol increases PPI in both WT and $\mathrm{G} \alpha \mathrm{s}^{*}$ transgenic mice (effect of drug: $\mathrm{F}_{(1,60)}=16.05, p<0.0005$; Figure $4 \mathrm{~b}$ ), resulting in a significant effect of genotype only in select trials (genotype $\times$ trial: $\mathrm{F}_{(2,60)}=5.62, p<0.01$ ). Post hoc analysis reveals that there is only a significant effect of genotype in this experiment at prepulse intensities of $76 \mathrm{~dB}(p<0.0005)$ and $84 \mathrm{~dB}(p<0.02)$. This appears to be because of a selective effect of haloperidol at the lowest prepulse intensity $(72 \mathrm{~dB})$ on PPI of $\mathrm{G} \alpha \mathrm{s}^{*}$ transgenic mice; however, the statistical interaction between genotype, drug, and trial did not reach the level of significance $\left(\mathrm{F}_{(2,60)}=2.23\right.$, $p=0.12)$. Haloperidol $(1.0 \mathrm{mg} / \mathrm{kg})$ also significantly reduces startle across genotypes (WT vehicle, 127.68 \pm 20.34 ; WT haloperidol, 85.61 \pm 10.36; G $\alpha \mathrm{s}^{*}$ vehicle, $100.59 \pm 12.48$; $\mathrm{G} \alpha \mathrm{s}^{*}$ haloperidol, $72.93 \pm 13.92$; effect of drug: $\mathrm{F}_{(2,63)}=8.10$, $p<0.002)$. It does not appear, however, that the effect of $1.0 \mathrm{mg} / \mathrm{kg}$ haloperidol on PPI is related to this effect on startle because startle magnitude does not correlate significantly with PPI at any prepulse intensity in either WT or G $\mathrm{Gs}^{*}$ mice. To determine if a lower dose of haloperidol would selectively affect PPI in G $\alpha s^{*}$ transgenic mice, we tested $0.1 \mathrm{mg} / \mathrm{kg}$ haloperidol. Across prepulse intensities, administration of $0.1 \mathrm{mg} / \mathrm{kg}$ haloperidol i.p. selectively increases PPI in G $\alpha s^{\star}$ transgenic mice without affecting WT littermates (genotype $\times$ drug: $\mathrm{F}_{(1,40)}=5.12$, $p<0.05$; post hoc $\mathrm{G} \alpha \mathrm{s}^{*}$ vehicle $v s$ WT vehicle, WT hal, and $\mathrm{G} \alpha \mathrm{s}^{*}$ hal, $p<0.01-0.0005$; Figure $\left.4 \mathrm{a}\right)$. This selective increase in PPI of $G \alpha s^{\star}$ mice does not appear to be because of alterations in the startle response itself. First, $0.1 \mathrm{mg} / \mathrm{kg}$ does not significantly affect startle magnitude (effect of drug: $\mathrm{F}_{(1,20)}=0.06$, NS; WT vehicle, $93.58 \pm 15.1$; WT haloperidol, $84.11 \pm 12.7 ; \mathrm{G} \mathrm{s}^{*}$ vehicle, $68.75 \pm 5.9 ; \mathrm{G} \alpha \mathrm{s}^{*}$ haloperidol, $61.85 \pm 9.6)$. Second, startle magnitude in $\mathrm{G} \alpha \mathrm{s}^{*}$ mice under $0.1 \mathrm{mg} / \mathrm{kg}$ haloperidol does not correlate with PPI at 

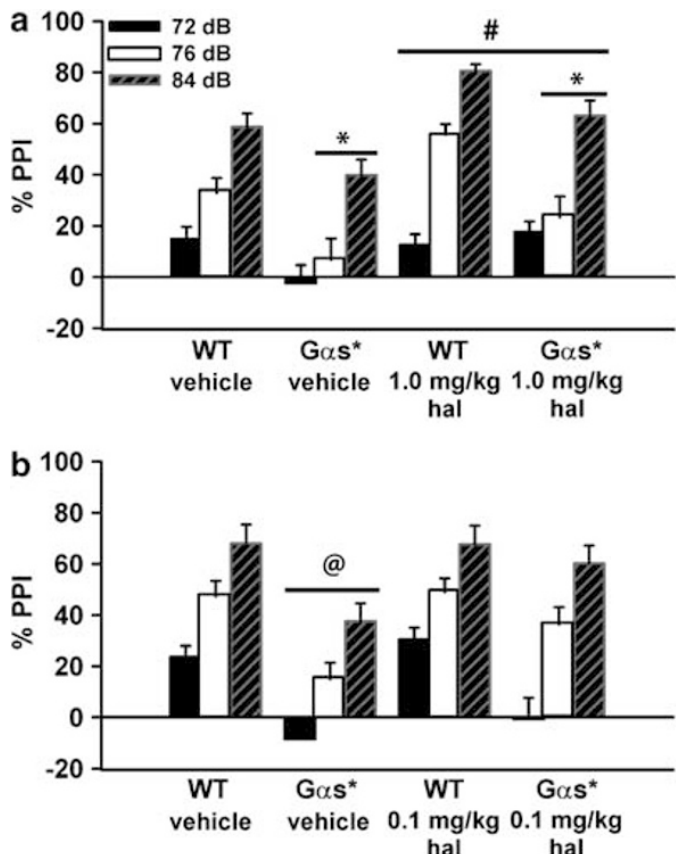

Figure 4 Antipsychotic haloperidol rescues PPI deficits of Gas* transgenic mice. (a) Injection of $1.0 \mathrm{mg} / \mathrm{kg}$ haloperidol ( $n=16$ per group) increases PPI in both WT and Gas* transgenic mice relative to vehicle, resulting in a significant effect of genotype only at 76 and $84 \mathrm{~dB}$ prepulse intensities. (b) A lower dose of $0.1 \mathrm{mg} / \mathrm{kg}$ haloperidol i.p. (hal) vs vehicle ( $n=1$ I per group) increases PPI only in Gas* transgenic mice, restoring levels to WT levels. Data represented as mean \pm SEM. ${ }^{@}$ vs WT vehicle, WT hal, and Gas* hal (post hoc), $p<0.01-0.0005$; *vs WT (main effect of genotype), $p<0.02-0.0005$; and ${ }^{\#}$ vs vehicle (main effect of treatment), $p<0.0005$.

prepulse intensities of 76 and $84 \mathrm{~dB}$ and, in fact, correlates positively with PPI at the $72 \mathrm{~dB}$ prepulse intensity $(r=0.757$, $p<0.01$ ).

Based on these behavioral results, we next determined in which brain regions $0.1 \mathrm{mg} / \mathrm{kg}$ haloperidol selectively normalizes cAMP levels in G $\alpha \mathrm{s}^{*}$ transgenic mice. Levels of cAMP were measured in the cortex, the hippocampus, and the striatum, as the previous experiment showed cAMP levels in these regions change as a function of transgene expression (Figure 2a). Levels were also measured in the cerebellum, as a control region. In the cortex, haloperidol selectively increases cAMP levels in G $\alpha s^{*}$ transgenic mice (genotype $\times$ drug: $\mathrm{F}_{(1,20)}=4.83, p<0.05$; post hoc $\mathrm{G} \alpha \mathrm{s}^{*}$ vehicle $v s$ WT vehicle and $\mathrm{G} \alpha \mathrm{s}^{*}$ hal, $p<0.05-0.01$; Figure 5 ); however, in the hippocampus, haloperidol increases cAMP levels in both WT and G $\alpha \mathrm{s}^{*}$ transgenic mice (effect of genotype: $\mathrm{F}_{(1,20)}=4.91, p<0.05$; effect of drug: $\mathrm{F}_{(1,20)}=6.42$, $p<0.02)$. In the striatum, haloperidol fails to attenuate the increased levels of cAMP noted in $\mathrm{G} \alpha \mathrm{s}^{*}$ transgenic mice (effect of genotype: $\mathrm{F}_{(1,14)}=4.77, p<0.05$ ), and in the cerebellum, haloperidol does not significantly alter cAMP levels (Figure 5).

\section{PPI Deficits of G $\alpha s^{\star}$ Transgenic Mice are Rescued by cAMP PDE Inhibition}

Because 'upstream' augmentation of the cAMP pathway by haloperidol was able to restore sensorimotor gating in $\mathrm{G} \alpha \mathrm{s}^{*}$

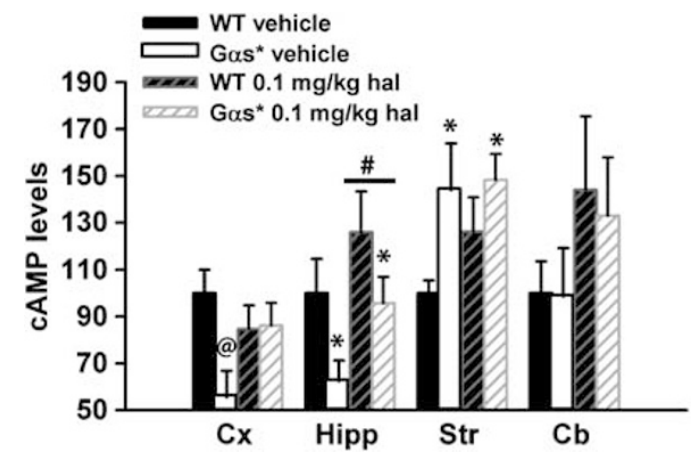

Figure 5 Antipsychotic haloperidol selectively rescues cortical cAMP levels in Gas* transgenic mice. Injection of $0.1 \mathrm{mg} / \mathrm{kg}$ haloperidol (WT, $n=5-6$; Gas*, $n=4-7$ ) vs vehicle (WT, $n=4-5$; Gas*, $n=5-6$ ) increases cAMP levels (\% WT vehicle) in the cortex of Gas* mice (Cx) and hippocampus of Gas* and WT mice (Hipp), but has no significant effect in the striatum (Str) or cerebellum (Cb). Data represented as mean \pm SEM. $@_{v s}$ WT vehicle and Gas* hal (post hoc), $p<0.05-0.01$; *vs WT (main effect of genotype), $p<0.05$; and ${ }^{\#} v s$ vehicle (main effect of treatment), $p<0.02$.

transgenic mice, we tested if 'downstream' modulation of the cAMP pathway at the level of cAMP PDEs would elicit the same effect. To block PKA signaling within forebrain neurons, and potentially the pathway to cAMP PDE upregulation, we crossed the $G \alpha s^{*}$ transgenic mice to $\mathrm{R}(\mathrm{AB})$ transgenic mice (Abel et al, 1997). Expression of both the $G \alpha s^{*}$ and $R(A B)$ transgenes within forebrain neurons increases PPI across trials, relative to expression of only $\mathrm{G} \alpha \mathrm{s}^{*}$ (effect of genotype: $\mathrm{F}_{(3,48)}=6.85, p<0.002$; post hoc $\mathrm{G} \alpha \mathrm{s}^{*}$ vs $\mathrm{WT}, \mathrm{R}(\mathrm{AB})$, and $\mathrm{G} \alpha \mathrm{s}^{*} \times \mathrm{R}(\mathrm{AB}), p<0.02-0.002$; Figure 6). This rescue of PPI occurs without a significant effect (effect of genotype: $\mathrm{F}_{(3,24)}=0.47$, NS) on startle responses to the $120 \mathrm{~dB}$ pulse alone (WT, $31.65 \pm 14.6$; $\mathrm{G} \alpha \mathrm{s}^{*}, \quad 45.45 \pm 13.3 ; \quad \mathrm{R}(\mathrm{AB}), \quad 46.03 \pm 12.2 ; \quad \mathrm{G} \alpha \mathrm{s}^{*} \times \mathrm{R}(\mathrm{AB})$, $29.87 \pm 9.1$ ). Further, there are no significant correlations between startle magnitude and PPI at any prepulse intensity for any genotype. To determine if PKA inhibition specifically rescues the $\mathrm{G} \alpha \mathrm{s}^{*}$-induced decrease, but not increase, in cAMP, levels were measured in the cortex and striatum, respectively. Coexpression of the $G \alpha \mathrm{s}^{*}$ and $\mathrm{R}(\mathrm{AB})$ transgenes rescues the decreased cortical cAMP levels (effect of genotype: $\mathrm{F}_{(3,27)}=5.79, p<0.005$; post hoc $\mathrm{G} \mathrm{s}^{*}$ vs WT, $\mathrm{R}(\mathrm{AB})$, and $\left.\mathrm{G} \alpha \mathrm{s}^{*} \times \mathrm{R}(\mathrm{AB}), p<0.05-0.005\right)$, but not the increased striatal cAMP levels, caused by G $\alpha \mathrm{s}^{*}$ expression alone (effect of genotype: $\mathrm{F}_{(3,27)}=27.93, p<0.0001$; post hoc $\mathrm{WT}$ and $\mathrm{R}(\mathrm{AB}) v s \mathrm{G} \alpha \mathrm{s}^{\star}$ and $\mathrm{G} \alpha \mathrm{s}^{\star} \times \mathrm{R}(\mathrm{AB}), p<0.001-0.0001$; Figure 7). These results are consistent with the finding that total cAMP PDE activity is not elevated in the hippocampus of $\mathrm{G} \alpha \mathrm{s}^{*} \times \mathrm{R}(\mathrm{AB})$ mice $(89.1 \pm 6.1 \%)$ relative to $\mathrm{WT}$ mice $(100.0 \pm 2.7 \%)$. These data show that $\mathrm{G} \alpha \mathrm{s}^{\star}$ expression leads to both PPI and cortical cAMP deficits through a PKAdependent pathway.

We also tested the effect of pharmacologically inhibiting cAMP PDE activity in $\mathrm{G} \alpha \mathrm{s}^{*}$ transgenic mice via i.p. injection of the PDE4 inhibitor rolipram. Rolipram $(0.66 \mathrm{mg} / \mathrm{kg})$ selectively increases PPI of $\mathrm{G} \alpha \mathrm{s}^{*}$ transgenic mice across trials (genotype $\times$ drug: $\mathrm{F}_{(1,60)}=5.64, p<0.03$; post hoc $\mathrm{G} \alpha \mathrm{s}^{*}$ vehicle vs WT vehicle, WT rolipram, and G $\alpha s^{\star}$ rolipram, $p<0.005-0.0005$; Figure 8). Analysis of the raw data 


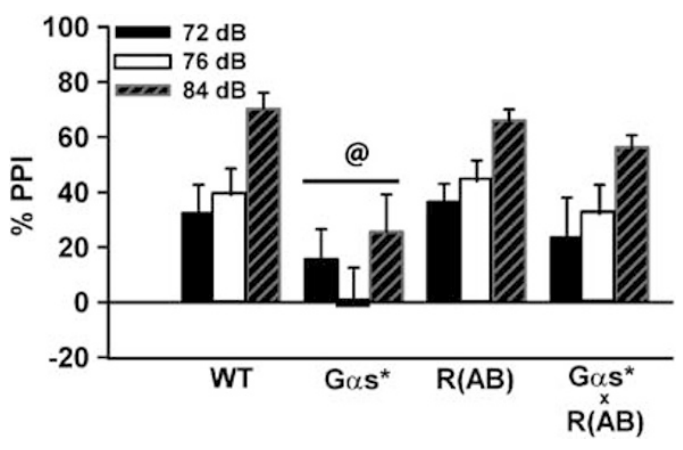

Figure 6 Genetic inhibition of PKA activity increases PPI in Gas* transgenic mice. Gas* transgenic mice $(n=6)$ exhibit reduced PPI relative to WT $(n=8), R(A B)$ transgenic mice (expressing an inhibitor of PKA activity; $n=7)$, and Gas* $\times R(A B)$ bitransgenic mice $(n=7)$. Data represented as mean $\pm S E M$. ${ }^{@}$ vs WT, R(AB), and Gas* $\times R(A B)$ (post hoc), $p<0.02-0.002$.

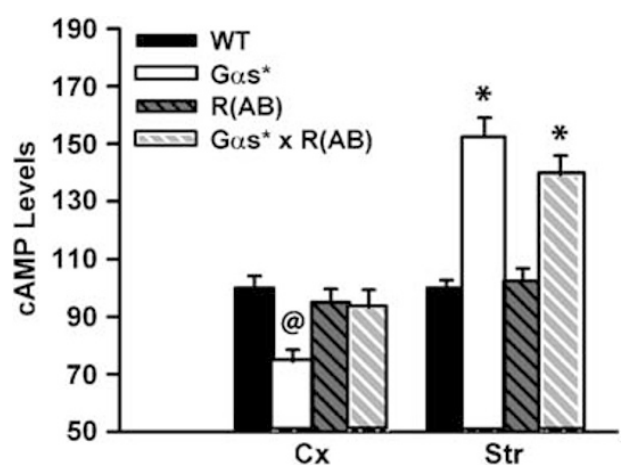

Figure 7 Genetic inhibition of PKA activity increases cortical cAMP levels in Gas* transgenic mice. Gas* transgenic mice $(n=7-8)$ exhibit reduced cAMP levels in the cortex relative to WT $(n=9), R(A B)$ transgenic mice $(n=\mid \mathrm{I})$, and Gas* $\times \mathrm{R}(\mathrm{AB})$ bitransgenic mice $(n=3)$; however, both Gas* transgenic mice and $G$ as* $\times R(A B)$ bitransgenic mice exhibit increased cAMP levels in striatum relative to $W T$ and $R(A B)$ transgenic mice. Data represented as mean $\pm S E M .{ }^{@}{ }_{V S} W T, R(A B)$, and $G \alpha s^{*} \times R(A B)$ (post hoc), $p<0.02-0.002$; *v WT and R(AB) (post hoc), $p<0.001-0.0001$.

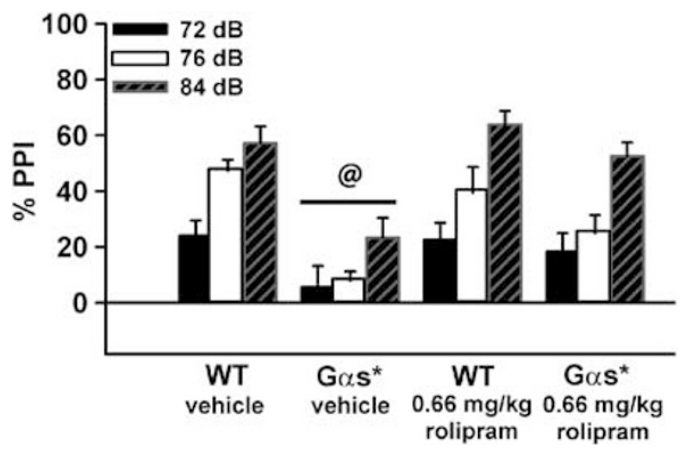

Figure 8 The PDE4 inhibitor rolipram restores PPI in Gas* transgenic mice. Following $0.66 \mathrm{mg} / \mathrm{kg}$ rolipram i.p., Gas* but not WT mice $(n=16$ per group) exhibit increased PPI. Data represented as mean \pm SEM. ${ }^{\circledR}$ VS WT vehicle, WT rolipram, and Gas* rolipram (post hoc), $p<0.005-0.0005$.

revealed significantly reduced startle responses (effect of genotype: $\left.F_{(1,30)}=9.87, p<0.005\right)$ to the $120 \mathrm{~dB}$ pulse in $G \alpha s^{*}$ mice across treatment conditions (WT vehicle, $83.54 \pm 9.5 ; \quad G \alpha s^{*}$ vehicle, $50.04 \pm 6.9 ; \quad$ WT rolipram,
$87.10 \pm 11.8 ; \mathrm{G}_{\alpha \mathrm{s}^{*}}$ rolipram $53.29 \pm 8.0$ ). Given that no significant change in startle has heretofore been observed in $\mathrm{G} \alpha \mathrm{s}^{\star}$ mice (under basal or saline vehicle conditions), it appears that this decrease in startle is elicited by the $2 \%$ DMSO vehicle employed in this study. Rolipram itself, however, does not significantly affect startle responses in either WT or $\mathrm{G} \alpha \mathrm{s}^{*}$ mice (effect of drug: $\mathrm{F}_{(1,30)=0.21}$, NS). Further, there are no significant correlations between startle magnitude and PPI at any prepulse intensity. This suggests that the selective increase in PPI exhibited by $G \alpha s^{*}$ mice following treatment with rolipram does not reflect a change in the startle response itself but rather increased sensorimotor gating.

\section{DISCUSSION}

Here, we show that constitutive activation of G $\alpha$ s signaling causes sensorimotor gating deficits because of PKAdependent decreases in cAMP. Expression of G $\alpha \mathrm{s}^{\star}$ within forebrain neurons causes increased cAMP levels in the striatum, but decreased cAMP levels in the cortex and hippocampus. Amphetamine, a pharmacological disruptor of sensorimotor gating, also regulates cAMP in a regionally specific manner, increasing cAMP levels in the striatum and decreasing levels in the cortex. Our results suggest it is the decreases in cAMP caused by these manipulations that trigger sensorimotor gating deficits. First, blocking cAMP signaling within the central nervous system using RpcAMPS is sufficient to induce deficits in PPI. Second, both the $\mathrm{D} 2$ antagonist haloperidol and the PKA inhibitor $\mathrm{R}(\mathrm{AB})$ increase PPI and cAMP levels in G $\alpha s^{\star}$ mice. Finally, downstream augmentation of cAMP signaling by the cAMP PDE inhibitor rolipram rescues G $\alpha s^{\star}$-induced PPI deficits. Thus, our work has defined cAMP as an intracellular signaling molecule regulating sensorimotor gating and, as a result, has identified cAMP PDE inhibitors as a novel class of potential antipsychotics.

Given that $\mathrm{G} \alpha \mathrm{s}^{*}$ expression causes a $115 \%$ increase in basal adenylyl cyclase activity, the question arises if the noted 16\% increase (average between the cortex and hippocampus) in total cAMP PDE activity could account for the decreased cAMP levels measured in the $G \alpha s^{*}$ transgenic mice. To gain insight into this issue, we used Michaelian kinetics to perform a steady-state modeling of cAMP accumulation using the Copasi modelling tool (http://www.copasi.org/tiki-index.php). This employed experimentally derived relative activities of these enzymes together with published $K_{\mathrm{m}}$ values for cAMP PDE $(2 \mu \mathrm{M}$ cAMP) and AC (80 nM ATP) activities. Inevitably, such a model makes assumptions and assumes a single $\mathrm{AC}$ and PDE species with full access of cAMP to all PDEs. Doing this, we could show that a relatively small $16 \%$ increase in PDE activity would be capable of considerably decreasing cAMP levels under normal conditions by some $70 \%$. When a two-fold increase in AC activity is introduced into the model, however, a $16 \%$ rise in PDE activity could not wholly account for the decreases in cAMP levels noted in the transgenic mice. Although PDEs are the only known proteins to degrade cAMP, there are also proteins that extrude cAMP from cells, referred to as multidrug resistance proteins (MRPs; Jedlitschky et al, 2000; Sampath 
et al, 2002). MRPs exist in nearly all tissues, including astrocytes, white matter, and pyramidal neurons of the brain (Nies et al, 2004). When this extrusion mechanism is introduced into the model ( $K_{\mathrm{m}}$ cAMP $\left.50 \mu \mathrm{M}\right)$, a 10 -fold increase in transporter activity is able to bring cAMP levels back to normal levels; however, the $16 \%$ increase in PDE activity now reduces cAMP levels only by $19 \%$ - well within the range of the transgenic experimental measurements. Therefore, we suggest that the overall reduction of cAMP levels noted in the $G \alpha s^{*}$ transgenic mice is likely because of an increase in cAMP PDE activity, as we show here, coupled with a proposed increase in cAMP efflux activity. Such a hypothesis is consistent with observations by Klamer et al (2005) who reported a correlation between increased extracellular cAMP levels in the hippocampus and PCPinduced PPI deficits. Extrusion of cAMP is likely to decrease intracellular signaling because cAMP is not membrane permeable (Schwede et al, 2000).

Given that inhibition of PKA within the forebrain is not sufficient to decrease PPI (Gould et al, 2004), and in fact rescues the transgenic deficits, the effect of decreased cAMP signaling on PPI is likely mediated through decreased signaling of other downstream targets of cAMP, such as Epac or cyclic nucleotide-gated channels. Future studies will examine possible mechanisms by which PKA mediates the effect of $\mathrm{G} \alpha \mathrm{s}^{*}$ expression on PPI and cortical cAMP deficits. Possible PKA-dependent mechanisms include the direct phosphorylation of specific cAMP PDE isoforms (eg PDE4), indirect phosphorylation of specific cAMP PDEs via crosstalk with members of the MAPK pathway, or increased CREB-dependent transcription of specific cAMP PDE isoforms (Figure 1a).

In addition to identifying cAMP as a key biochemical substrate, our results identify cortex as a key anatomical substrate mediating the effect of $G \alpha s^{*}$ on PPI. Across experiments, cAMP levels within cortex reliably correlate with PPI measures (see Table 2 for summary). This is consistent with the integral position that the cortex holds in the neural circuitry underlying PPI modulation (Koch, 1999; Swerdlow et al, 2001a, b; Goto et al, 2002). For example, excitotoxic lesions within the entorhinal cortex of adult rats cause PPI deficits (Goto et al, 2002). Interestingly, decreased cAMP signaling may also play a role in these PPI deficits given that electrolytic lesions increase high-affinity binding states of G $\alpha$ i-coupled D2 receptors (Sumiyoshi et al, 2005) and are partially reversed by haloperidol (Goto et al, 2002). Although we measure an overall increase in AC activity in $\mathrm{G} \alpha \mathrm{s}^{*}$ transgenic mice, our results suggest that $\mathrm{G} \alpha \mathrm{s}^{*}$ expression also leads to increased activation of D2 receptors in the cortex (perhaps in localized microdomains) as the transgenic mice are more sensitive, relative to WT mice, to the behavioral and biochemical effects of haloperidol. Further, the ability of amphetamine to reduce cAMP levels in the cortex is consistent with a preferential activation of D2/D4 receptors (Figure 1a; Neves et al, 2002), although a role for an alternative neurotransmitter system (eg norepinephrine) cannot be ruled out. It will be of interest in future studies to determine if psychotomimetic drugs targeting the glutamatergic system (eg PCP) decrease cortical cAMP levels, as does amphetamine, and if atypical antipsychotics (eg clozapine) increase cortical cAMP levels, as does haloperidol. An alteration in cortical cAMP signaling stands to substantially influence neural processes not only within this region but also within other PPImodulating regions, as cortex projects to the hippocampus, the NAcc, and the VTA (Koch, 1999; Swerdlow et al, 2001a, b; Goto et al, 2002).

The identification of cAMP as a biochemical substrate mediating the effects of $\mathrm{G} \alpha \mathrm{s}^{\star}$ on sensorimotor gating advances our mechanistic understanding of preattentional processing and opens new avenues for the pursuit of therapeutic interventions. The extent to which antipsychotic medications increase PPI in rodent models correlates positively with clinical efficacy (Swerdlow and Geyer, 1998; Geyer et al, 2001). Thus, our study showing that rolipram increases PPI in transgenic mice further bolsters support for cAMP PDE inhibitors as a novel class of receptor-independent antipsychotics (Maxwell et al, 2004; Davis and Gould, 2005). Rolipram has largely been characterized as an antidepressant (cf., O'Donnell and Zhang, 2004); however, the effect of rolipram on PPI is likely unrelated to its efficacy as an antidepressant because

Table 2 Summary of Manipulations Affecting cAMP Signallinga, Startle Responses, PPI, and Sensorimotor Gating ${ }^{b}$

\begin{tabular}{|c|c|c|c|c|c|c|}
\hline Manipulation & $\begin{array}{l}\text { CAMP } \\
\text { signalling } \\
\text { cortex }\end{array}$ & $\begin{array}{l}\text { CAMP } \\
\text { signalling } \\
\text { striatum }\end{array}$ & $\begin{array}{c}\text { CAMP } \\
\text { signalling } \\
\text { hipp }\end{array}$ & $\begin{array}{c}\text { Startle } \\
\text { magnitude }\end{array}$ & \%PPI & $\begin{array}{c}\text { Sensorimotor } \\
\text { gating }\end{array}$ \\
\hline Gas* transgene & $\downarrow$ & $\uparrow$ & $\downarrow$ & $\leftrightarrow^{c}$ & $\downarrow$ & $\downarrow$ \\
\hline Amphetamine ( $10 \mathrm{mg} / \mathrm{kg}$ in C57BL/6) mice) & $\downarrow$ & $\uparrow$ & $\leftrightarrow$ & $\downarrow$ & $\downarrow$ & $\downarrow$ \\
\hline Haloperidol (0.1 mg/kg in Gas* mice) & $\uparrow$ & $\leftrightarrow$ & $\uparrow$ & $\leftrightarrow$ & $\uparrow$ & $\uparrow$ \\
\hline Rolipram (0.66 mg/kg in Gas* mice) & $\uparrow$ & $\uparrow$ & $\uparrow$ & $\leftrightarrow$ & $\uparrow$ & $\uparrow$ \\
\hline
\end{tabular}

aA manipulation affects cAMP signaling when it affects cAMP binding to downstream targets (ie Rp-cAMPS) or it changes cAMP levels (ie all other manipulations).

${ }^{\mathrm{b}} \mathrm{A}$ manipulation affects sensorimotor gating when it alters the ability of a prepulse to inhibit the startle response without significantly affecting the magnitude of the startle response itself in the opposite direction (Swerdlow et al, 2000).

${ }^{\mathrm{C}}$ Effect of transgene under basal conditions (no injection) and following treatment with a saline vehicle. Treatment with a $2 \%$ DMSO vehicle significantly reduced startle responses in transgenic mice; however, PPI was still reduced.

$\uparrow$, significant increase; $\downarrow$, significant decrease; $\leftrightarrow$, no statistically significant change; and NM, not measured. 
other antidepressants do not systematically affect PPI in rodents (Geyer et al, 2001) or humans (Braff et al, 2001). Rolipram also enhances memory (Barad et al, 1998; Bourtchouladze et al, 2003; Zhang et al, 2004). This, coupled with the effect of rolipram on PPI, suggests that cAMP PDE inhibitors may prove successful in treating the debilitating cognitive deficits that are associated with schizophrenia. In fact, future studies will explore if rolipram is able to reverse the cognitive deficits exhibited by $\mathrm{G} \alpha \mathrm{s}$ transgenic mice (Kelly et al, 2003). Further, given the role of PDE4 in NMDA receptor signaling (eg Suvarna and O'Donnell, 2002), future studies will also examine the potential role of hypoglutamatergic functioning in $\mathrm{G} \alpha \mathrm{s}$ induced behavioral and biochemical deficits. It is important to note that, in rodent models, rolipram combats the detrimental motoric side effects of long-term haloperidol administration (Sasaki et al, 1995). This suggests that new drugs targeting the cAMP pathway intracellularly may be better tolerated than current medications that modulate signaling pathways extracellularly via neurotransmitter receptors.

We conclude that cortical cAMP is a key biochemical regulator mediating the effects of $\mathrm{G} \alpha \mathrm{s}^{*}$ on sensorimotor gating and that rolipram exhibits antipsychotic-like therapeutic properties. Given the large number of manipulations that are capable of altering sensorimotor gating (cf., Geyer et al, 2001, 2002; Swerdlow et al, 2001a), it is clear that the molecular and neural circuits regulating this automatic neural process are quite complex. Our work, and those of others measuring region-specific effects (eg Svenningsson et al, 2003), suggests another layer of complexity in the regulation of sensorimotor gating in that each brain region may have a unique molecular signature.

\section{ACKNOWLEDGEMENTS}

We thank Raquel Gur, Tom Gould, and Conor McDonough for thoughtful discussions on this project. This work was supported by grants from the Merck, Whitehall, and Packard Foundations as well as NIMH R01 MH60244, NIA R01 AG18199, and P50 MH 6404501, Project 3 to TA (R Gur, Conte Center PI), who is a John Merck Scholar and a David and Lucile Packard Foundation Fellow. Additional support includes NIMH K08 MH067091 to SJK, NIAA AA09000 to GW, and a Tourette's Syndrome Association Fellowship to MPK, who is also supported by NIMH T32 MH019112 (R Gur, PI). Finally, MDH thanks the Medical Research Council (UK) (G8604010) and the European Union (QLK3-CT-200202149) for funding.

\section{REFERENCES}

Abel T, Nguyen PV, Barad M, Deuel TA, Kandel ER, Bourtchouladze R (1997). Genetic demonstration of a role for PKA in the late phase of LTP and in hippocampus-based long-term memory. Cell 88: 615-626.

Avissar S, Barki-Harrington L, Nechamkin Y, Roitman G, Schreiber G (2001). Elevated dopamine receptor-coupled G(s) protein measures in mononuclear leukocytes of patients with schizophrenia. Schizophrenia Res 47: 37-47.
Bakshi VP, Geyer MA (1999). Ontogeny of isolation rearinginduced deficits in sensorimotor gating in rats. Physiol Behav 67: 385-392.

Barad M, Bourtchouladze R, Winder DG, Golan H, Kandel E (1998). Rolipram, a type IV-specific phosphodiesterase inhibitor, facilitates the establishment of long-lasting long-term potentiation and improves memory. Proc Natl Acad Sci USA 95: $15020-15025$.

Beavo JA, Brunton LL (2002). Cyclic nucleotide research-still expanding after half a century. Nat Rev Mol Cell Biol 3: 710-718.

Berndt S, Schwabe U (1973). Effect of psychotropic drugs on phosphodiesterase and cyclic AMP level in rat brain in vivo. Brain Res 63: 303-312.

Bourtchouladze R, Abel T, Berman N, Gordon R, Lapidus K, Kandel ER (1998). Different training procedures recruit either one or two critical periods for contextual memory consolidation, each of which requires protein synthesis and PKA. Learn Mem 5: 365-374.

Bourtchouladze R, Lidge R, Catapano R, Stanley J, Gossweiler S, Romashko D et al (2003). A mouse model of Rubinstein-Taybi syndrome: defective long-term memory is ameliorated by inhibitors of phosphodiesterase 4. Proc Natl Acad Sci USA 100: 10518-10522.

Braff D, Stone C, Callaway E, Geyer M, Glick I, Bali L (1978). Prestimulus effects on human startle reflex in normals and schizophrenics. Psychophysiology 15: 339-343.

Braff DL, Geyer MA, Swerdlow NR (2001). Human studies of prepulse inhibition of startle: normal subjects, patient groups, and pharmacological studies. Psychopharmacology 156: 234-258.

Carenzi A, Cheney DL, Costa E, Guidotti A, Racagni G (1975). Action of opiates, antipsychotics, amphetamine and apomorphine on dopamine receptors in rat striatum: in vivo changes of $3^{\prime}, 5^{\prime}$-cyclic AMP content and acetylcholine turnover rate. Neuropharmacology 14: 927-939.

Castellanos FX, Fine EJ, Kaysen D, Marsh WL, Rapoport JL, Hallett M (1996). Sensorimotor gating in boys with Tourette's syndrome and ADHD: preliminary results. Biol Psychiatry 39: 33-41.

Chetkovich DM, Sweatt JD (1993). NMDA receptor activation increases cyclic AMP in area CA1 of the hippocampus via calcium/calmodulin stimulation of adenylyl cyclase. J Neurochem 61: 1933-1942.

Davis JA, Gould TJ (2005). Rolipram attenuates MK-801-induced deficits in latent inhibition. Behav Neurosci 119: 595-602.

Dwivedi Y, Rizavi HS, Pandey GN (2002). Differential effects of haloperidol and clozapine on [(3)H]cAMP binding, protein kinase A (PKA) activity, and mRNA and protein expression of selective regulatory and catalytic subunit isoforms of PKA in rat brain. J Pharmacol Exp Therap 301: 197-209.

Frankland PW, Wang Y, Rosner B, Shimizu T, Balleine BW, Dykens EM et al (2004). Sensorimotor gating abnormalities in young males with fragile $\times$ syndrome and Fmr1-knockout mice. Mol Psychiatry 9: 417-425.

Frantz S (2005). Drug discovery: playing dirty. Nature 437: 942-943.

Frey UH, Eisenhardt A, Lummen G, Rubben H, Jockel KH, Schmid $\mathrm{KW}$ et al (2005). The T393C polymorphism of the $\mathrm{G}$ alpha s gene (GNAS1) is a novel prognostic marker in bladder cancer. Cancer Epidemiol Biomar Prevent 14: 871-877.

Geyer MA, Krebs-Thomson K, Braff DL, Swerdlow NR (2001). Pharmacological studies of prepulse inhibition models of sensorimotor gating deficits in schizophrenia: a decade in review. Psychopharmacology 156: 117-154.

Geyer MA, McIlwain KL, Paylor R (2002). Mouse genetic models for prepulse inhibition: an early review. Mol Psychiatry 7: 1039-1053.

Goto K, Ueki A, Iso H, Morita Y (2002). Reduced prepulse inhibition in rats with entorhinal cortex lesions. Behav Brain Res 134: 201-207. 
Gould TJ, Bizily SP, Tokarczyk J, Kelly MP, Siegel SJ, Kanes SJ et al (2004). Sensorimotor gating deficits in transgenic mice expressing a constitutively active form of Gs alpha. Neuropsychopharmacology 29: 494-501.

Graham FK (1975). Presidential Address, 1974. The more or less startling effects of weak prestimulation. Psychophysiology 12: 238-248.

Hoenig K, Hochrein A, Quednow BB, Maier W, Wagner M (2005). Impaired prepulse inhibition of acoustic startle in obsessivecompulsive disorder. Biol Psychiatry 57: 1153-1158.

Houslay MD, Adams DR (2003). PDE4 cAMP phosphodiesterases: modular enzymes that orchestrate signalling cross-talk, desensitization and compartmentalization. Biochem J 370: 1-18.

Jedlitschky G, Burchell B, Keppler D (2000). The multidrug resistance protein 5 functions as an ATP-dependent export pump for cyclic nucleotides. J Biol Chem 275: 30069-30074.

Kaiya H (1992). Second messenger imbalance hypothesis of schizophrenia. Prostaglandins Leukotrienes Essent Fatty Acids 46: $33-38$

Kaneko M, Sato K, Horikoshi R, Yaginuma M, Yaginuma N, Shiragata M et al (1992). Effect of haloperidol on cyclic AMP and inositol trisphosphate in rat striatum in vivo. Prostaglandins Leukotrienes Essent Fatty Acids 46: 53-57.

Kaplan GB, Leite-Morris KA, Keith DJ (1999). Differential effects of treatment with typical and atypical antipsychotic drugs on adenylyl cyclase and G proteins. Neurosci Lett 273: 147-150.

Kebabian JW, Petzold GL, Greengard P (1972). Dopamine-sensitive adenylate cyclase in caudate nucleus of rat brain, and its similarity to the 'dopamine receptor'. Proc Natl Acad Sci USA 69: 2145-2149.

Kelly MP, Tokarczyk J, Rapoport DA, Godfrey M, Kanes SJ, Abel T (2003). Modeling cognitive deficits of schizophrenia in mice with altered G-protein signaling. Society Neurosci Abstr 29: 858.2.

Klamer D, Palsson E, Fejgin K, Zhang J, Engel JA, Svensson L (2005). Activation of a nitric-oxide-sensitive cAMP pathway with phencyclidine: elevated hippocampal cAMP levels are temporally associated with deficits in prepulse inhibition. Psychopharmacology 179: 479-488.

Koch M (1999). The neurobiology of startle. Prog Neurobiol 59: 107-128.

Kopperud R, Krakstad C, Selheim F, Doskeland SO (2003). cAMP effector mechanisms. Novel twists for an 'old' signaling system. FEBS Lett 546: 121-126.

Lania A, Persani L, Ballare E, Mantovani S, Losa M, Spada A (1998). Constitutively active Gs alpha is associated with an increased phosphodiesterase activity in human growth hormone-secreting adenomas. J Clin Endocrinol Metab 83: 1624-1628.

Lee R, Wolda S, Moon E, Esselstyn J, Hertel C, Lerner A (2002). PDE7A is expressed in human B-lymphocytes and is upregulated by elevation of intracellular cAMP. Cell Signal 14: 277-284.

Ludewig S, Geyer MA, Ramseier M, Vollenweider FX, Rechsteiner E, Cattapan-Ludewig K (2005). Information-processing deficits and cognitive dysfunction in panic disorder. I Psychiatry Neurosci 30: 37-43.

MacKenzie SJ, Baillie GS, McPhee I, MacKenzie C, Seamons R, McSorley $\mathrm{T}$ et al (2002). Long PDE4 cAMP specific phosphodiesterases are activated by protein kinase A-mediated phosphorylation of a single serine residue in upstream conserved region 1 (UCR1). Br J Pharmacol 136: 421-433.

Maxwell CR, Kanes SJ, Abel T, Siegel SJ (2004). Phosphodiesterase inhibitors: a novel mechanism for receptor-independent antipsychotic medications. Neurosci 129: 101-107.

Memo M, Kleinman JE, Hanbauer I (1983). Coupling of dopamine D1 recognition sites with adenylate cyclase in nuclei accumbens and caudatus of schizophrenics. Science 221: 1304-1307.
Millar JK, Pickard BS, Mackie S, James R, Christie S, Buchanan SR et al (2005). DISC1 and PDE4B are interacting genetic factors in schizophrenia that regulate cAMP signaling. Science 310: 1187-1191.

Minoretti P, Politi P, Coen E, Di Vito C, Bertona M, Bianchi M et al (2006). The T393C polymorphism of the GNAS1 gene is associated with deficit schizophrenia in an Italian population sample. Neurosci Lett 397: 159-163.

Miyamoto S, Duncan GE, Marx CE, Lieberman JA (2005). Treatments for schizophrenia: a critical review of pharmacology and mechanisms of action of antipsychotic drugs. Mol Psychiatry 10: 79-104.

Murthy KS, Zhou H, Makhlouf GM (2002). PKA-dependent activation of PDE3A and PDE4 and inhibition of adenylyl cyclase V/VI in smooth muscle. Am J Phys Cell Phys 282: C508-C517.

Neves SR, Ram PT, Iyengar R (2002). G protein pathways. Science 296: 1636-1639.

Nies AT, Jedlitschky G, Konig J, Herold-Mende C, Steiner HH, Schmitt HP et al (2004). Expression and immunolocalization of the multidrug resistance proteins, MRP1-MRP6 (ABCC1ABCC6), in human brain. Neuroscience 129: 349-360.

O'Donnell JM, Zhang HT (2004). Antidepressant effects of inhibitors of cAMP phosphodiesterase (PDE4). Trends Pharmacol Sci 25: 158-163.

Ouagazzal AM, Jenck F, Moreau JL (2001). Drug-induced potentiation of prepulse inhibition of acoustic startle reflex in mice: a model for detecting antipsychotic activity? Psychopharmacologia 156: 273-283.

Perry W, Minassian A, Feifel D, Braff DL (2001). Sensorimotor gating deficits in bipolar disorder patients with acute psychotic mania. Biol Psychiatry 50: 418-424.

Perry W, Minassian A, Lopez B, Maron L, Lincoln A (2006). Sensorimotor gating deficits in adults with autism. Biol Psychiatry (doi:10.1016/j.biopsych.2005.09.025)

Quednow BB, Kuhn KU, Beckmann K, Westheide J, Maier W, Wagner M (2006). Attenuation of the prepulse inhibition of the acoustic startle response within and between sessions. Biol Psychol 71: 256-263.

Ralph-Williams RJ, Lehmann-Masten V, Otero-Corchon V, Low MJ, Geyer MA (2002). Differential effects of direct and indirect dopamine agonists on prepulse inhibition: a study in D1 and D2 receptor knock-out mice. J Neurosci 22: 9604-9611.

Rochais F, Vandecasteele G, Lefebvre F, Lugnier C, Lum H, Mazet JL et al (2004). Negative feedback exerted by cAMP-dependent protein kinase and cAMP phosphodiesterase on subsarcolemmal cAMP signals in intact cardiac myocytes: an in vivo study using adenovirus-mediated expression of CNG channels. J Biol Chem 279: 52095-52105.

Salomon Y, Londos C, Rodbell M (1974). A highly sensitive adenylate cyclase assay. Anal Biochem 58: 541-548.

Sampath J, Adachi M, Hatse S, Naesens L, Balzarini J, Flatley RM et al (2002). Role of MRP4 and MRP5 in biology and chemotherapy. AAAPS Pharm Sci 4: E14.

Sandor P (2003). Pharmacological management of tics in patients with TS. J Psychosom Res 55: 41-48.

Sasaki H, Hashimoto K, Maeda Y, Inada T, Kitao Y, Fukui S et al (1995). Rolipram, a selective c-AMP phosphodiesterase inhibitor suppresses oro-facial dyskinetic movements in rats. Life Sci 56: L443-L447.

Sawa A, Snyder SH (2002). Schizophrenia: diverse approaches to a complex disease. Science 296: 692-695.

Schwede F, Maronde E, Genieser H, Jastorff B (2000). Cyclic nucleotide analogs as biochemical tools and prospective drugs. Pharmacol Therap 87: 199-226.

Singer HS, Hahn IH, Krowiak E, Nelson E, Moran T (1990). Tourette's syndrome: a neurochemical analysis of postmortem cortical brain tissue. Ann Neurol 27: 443-446. 
Sumiyoshi T, Seeman P, Uehara T, Itoh H, Tsunoda M, Kurachi M (2005). Increased proportion of high-affinity dopamine D2 receptors in rats with excitotoxic damage of the entorhinal cortex, an animal model of schizophrenia. Brain Res Mol Brain Res 140: 116-119.

Suvarna NU, O’Donnell JM (2002). Hydrolysis of N-methyl-Daspartate receptor-stimulated cAMP and cGMP by PDE4 and PDE2 phosphodiesterases in primary neuronal cultures of rat cerebral cortex and hippocampus. J Pharmacol Exp Therap 302: 249-256.

Svenningsson P, Tzavara ET, Carruthers R, Rachleff I, Wattler S, Nehls $M$ et al (2003). Diverse psychotomimetics act through a common signaling pathway. Science 302: 1412-1415.

Swerdlow NR, Geyer MA (1998). Using an animal model of deficient sensorimotor gating to study the pathophysiology and new treatments of schizophrenia. Schizophrenia Bull 24: 285-301.

Swerdlow NR, Geyer MA, Braff DL (2001a). Neural circuit regulation of prepulse inhibition of startle in the rat: current knowledge and future challenges. Psychopharmacology 156: 194-215.
Swerdlow NR, Hanlon FM, Henning L, Kim YK, Gaudet I, Halim ND (2001b). Regulation of sensorimotor gating in rats by hippocampal NMDA: anatomical localization. Brain Res 898: 195-203.

Swerdlow NR, Martinez ZA, Hanlon FM, Platten A, Farid M, Auerbach $\mathrm{P}$ et al (2000). Toward understanding the biology of a complex phenotype: rat strain and substrain differences in the sensorimotor gating-disruptive effects of dopamine agonists. $J$ Neurosci 20: 4325-4336.

Swerdlow NR, Paulsen J, Braff DL, Butters N, Geyer MA, Swenson MR (1995). Impaired prepulse inhibition of acoustic and tactile startle response in patients with Huntington's disease. J Neurol, Neurosurg Psychiatry 58: 192-200.

Wand G, Levine M, Zweifel L, Schwindinger W, Abel T (2001). The cAMP-protein kinase A signal transduction pathway modulates ethanol consumption and sedative effects of ethanol. J Neurosci 21: 5297-5303.

Zhang HT, Zhao Y, Huang Y, Dorairaj NR, Chandler LJ, O'Donnell JM (2004). Inhibition of the phosphodiesterase 4 (PDE4) enzyme reverses memory deficits produced by infusion of the MEK inhibitor U0126 into the CA1 subregion of the rat hippocampus. Neuropsychopharmacology 29: 1432-1439. 